\title{
MARGIN PEMASARAN BUAH SALAK DI DESA PANGU DUA KECAMATAN RATAHAN TIMUR KABUPATEN MINAHASA TENGGARA
}

\author{
Regina Pangkey \\ Celcius Talumingan \\ Melissa Lady G. Tarore
}

\begin{abstract}
This study aims to determine the pattern of marketing, calculate the amount of costs, margins and marketing benefits and farmer's share in Pangu Dua Village, which was held from June to August 2018. The data used in this study are primary and secondary data. Primary data is data obtained by submitting a list of questions to farmers 10 respondents, collecting traders 5 respondents, retailers 3 respondents in Pangu Dua Village. While secondary data was obtained from Pangu Dua Village Office, and the internet. Data analysis in this study uses marketing channel analysis and marketing margin analysis. The results of the study show that there are four forms of marketing channels in Pangu Dua Village. Marketing channel I consists of farmers and consumers; marketing channel II consists of farmers, retailers, consumers; marketing channel III consists of farmers, collectors, supermarkets retailers and consumers; marketing channel IV consists of farmers, collectors and wholesalers between islands. Marketing channel III has the highest value, namely the cost of Rp. 345 per kilogram, margin of Rp. 11,000 per kilogram, and profit of Rp. 10,655 per kilogram. The highest portion received by farmers (farmer's share) on marketing channel I is 100 percent. This research support the result of previous study by Kaparang's 2015 that the greater the marketing margin, the smaller the portion received by farmers, on the contrary the smaller the marketing margin the greater the portion received by farmers, can be accepted in this study. ${ }^{*}$ ind + eprm*
\end{abstract}

Keywords: marketing margin, salak fruit, Pangu Dua Village.

\begin{abstract}
ABSTRAK
Penelitian ini bertujuan untuk mengetahui pola pemasaran, menghitung besarnya biaya, margin dan keuntungan pemasaran serta farmer's share di Desa Pangu Dua, yang dilaksanakan sejak bulan Juni sampai Agustus tahun 2018. Data yang digunakan dalam penelitian ini adalah data primer dan sekunder. Data primer yaitu data yang diperoleh dengan mengajukan daftar pertanyaan kepada petani 10 responden, pedagang pengumpul 5 responden, pedagang pengecer 3 responden di Desa Pangu Dua. Sedangkan data sekunder diperoleh dari Kantor Desa Pangu Dua, dan internet. Analisis data dalam penelitian ini menggunkan analisis saluran pemasaran dan analisis margin pemasaran. Hasil penelitian menunjukkan bahwa ada empat bentuk saluran pemasaran di Desa Pangu Dua,. Saluran pemasaran I terdiri atas petani dan konsumen; saluran pemasaran II terdiri atas petani, pengecer, konsumen; saluran pemasaran III terdiri atas petani, pedagang pengumpul, pedagang pengecer pasar swalayan dan konsumen; saluran pemasaran IV terdiri atas petani, pedagang pengumpul dan pedagang besar antar pulau. Saluran pemasaran III memiliki nilai tertinggi yaitu biaya sebesar Rp 345 per kilogram, margin sebesar Rp 11.000 per kilogram, dan keuntungan sebesar Rp 10.655 per kilogram. Bagian yang diterima petani (farmer's share) tertinggi pada saluran pemasaran I yaitu sebesar 100 persen. Penelitian ini mendukung temuan sebelumnya yang dilakukan oleh Kaparang 2015 yaitu semakin besar margin pemasaran maka semakin kecil bagian yang diterima oleh petani, sebaliknya semakin kecil margin pemasaran semakin besar bagian yang diterima oleh petani, dapat diterima dalam penelitian ini. ${ }^{*}$ ind + eprm*
\end{abstract}

Kata kunci: margin pemasaran, buah salak, Desa Pangu Dua

\section{PENDAHULUAN}

\section{Latar Belakang}

Sektor pertanian sangat penting dalam perkembangan perekonomian Indonesia, maka diperlukan adanya suatu upaya pembangunan yang mengarah pada pengembangan sektor pertanian yang tangguh. Menurut (Rorenkeu 2005) dalam (Fatimah, 2011), visi pembangunan pertanian periode 2005 - 2009 adalah terwujudnya pertanian tangguh untuk pemantapan ketahanan pangan, peningkatan nilai tambah dan daya saing produk pertanian serta peningkatan kesejahteraan petani. 
Komoditas hortikultura adalah kelompok komoditas yang terdiri dari buah-buahan, sayuran, tanaman hias dan tanaman biofarmaka. Komoditas buah-buahan merupakan salah satu komoditas hortikultura yang memiliki kontribusi besar dalam pengembangan pertanian di Indonesia (BPS dan Direktorat Jendral Hortikultura, 2007).

Di Sulawesi Utara di kenal dengan dua varietas salak yaitu varietas zalacca terdapat di Tagulandang Sangihe Talaud dan varietas amboinensis di desa Pangu, Minahasa Tenggara (Darmadi, 2001 dalam Manurung dkk, 2008). Ketersediaan buah salak di daerah Sulawesi Utara khus usnya Desa Pangu, Kecamatan Ratahan Timur Minahasa Tenggara melimpah, karena memang salak pangu dikenal cepat berbuah, antara $3-4$ tahun. Kegiatan pemanenan buah salak ini bisa dilakukan 2 kali dalam sebulan. Sekali panen dalam satu hektar bisa menghasilkan sekira $625-1000 \mathrm{~kg}$ buah salak.

Data Dinas Pertanian Kabupaten Minahasa Tenggara tahun 2014 menunjukkan bahwa Kecamatan Ratahan Timur khususnya wilayah Pangu yang terdiri dari Pangu Induk, Pangu Satu, Pangu Dua merupakan wilayah yang memiliki potensi pengembangan usaha tani buah salak dengan produksi buah salak mencapai 44.256 ton dan jumlah tanaman yang menghasilkan sebanyak 553.200 pohon (Tambulus 2015) dengan rincian seperti pada Tabel 1.

Tabel 1. Jumlah Tanaman Salak Produktif dan Produksi di Wilayah Pangu

\begin{tabular}{lcc}
\hline \multicolumn{1}{c}{ Desa } & $\begin{array}{c}\text { Tanaman Produktif } \\
\text { (Pohon) }\end{array}$ & Produksi (ton) \\
\hline Pangu Induk & 175.200 & 14.061 \\
Pangu Satu & 258.000 & 20.640 \\
Pangu Dua & 120.000 & 9.600 \\
\hline Total & 553.000 & 44.256 \\
\hline Sumber $:$ & BP3K Kecamatan Ratahan Timur & (2014) dalam \\
& Tambulus (2015) &
\end{tabular}

Kecamatan Ratahan Timur merupakan salah satu kecamatan di Kabupaten Minahasa Tenggara yang dikenal sebagai daerah penghasil buah salak yang khususnya terletak di Desa Pangu. Seiring dengan berkembangnya ilmu pengetahuan dan teknologi, pengolahan salak terus berkembang. Sektor pertanian hingga saat ini masih tetap menjadi tumpuan pertumbuhan ekonomi daerah Provinsi Sulawesi Utara (Sondakh dkk, 2008 dalam R. F Woran dkk, 2018).

Desa Pangu Kecamatan Ratahan Timur merupakan salah satu sentra pertanian buah salak. Karena dilihat dari volume produksi dan pola pemasaran lebih dominan di daerah ini. Besarnya jumlah produksi dan konsumsi buah salak di Desa Pangu Kecamatan Ratahan Timur ini belum mencerminkan sistem pemasaran yang efisien, terutama bila dilihat dari keuntungan dan harga yang diterima petani atau produsen buah salak. Keuntungan buah salak ini dapat dilihat dari margin pemasaran. Margin pemasaran merupakan harga yang di berikan konsumen akhir kepada petani produsen. Atau dengan kata lain, margin pemasaran merupakan selisih harga antara konsumen dan petani produsen. Permasalahan yang sering dihadapi dalam mewujudkan pemasaran buah salak adalah tinggi rendahnya tingkat harga yang diterima petani erat kaitannya dengan sistem pemasaran yang terjadi dan besar kecilnya margin pemasaran, sehingga untuk meningkatkan pemasaran buah salak dapat dicapai apabila margin pemasaran dapat diketahui. Hal tersebut yang mendorong penulis untuk melakukan penelitian sehingga dapat mengetahui lebih lanjut mengenai margin pemasaran dari buah salak di Desa Pangu Dua Kecamatan Ratahan Kabupaten Minahasa Tenggara.

\section{Rumusan Masalah}

adalah:

Rumusan masalah dalam penelitian ini

1. Bagaimana pola saluran pemasaran di Desa Pangu Dua?

2. Berapa besar biaya, keuntungan dan margin pemasaran di setiap saluran pemasaran buah salak di Desa Pangu Dua?

3. Bagaimana farmer's share di setiap saluran pemasaran di Desa Pangu Dua?

\section{Tujuan Penelitian}

Tujuan dari penelitian ini untuk:

1. Menganalisis pola saluran pemasaran di Desa Pangu Dua.

2. Menganalisis besarnya biaya, keuntungan dan margin pemasaran buah salak di desa Pangu Dua dan menentukan yang paling menguntungkan.

3. Menganalisis farmer's share di setiap saluran pemasaran di Desa Pangu Dua dan menentukan yang paling menguntungan.

\section{Manfaat Penelitian}

1. Manfaat dalam penelitian ini yaitu, untuk memberikan informasi bagi petani buah salak di Desa Pangu Dua tentang pemasaran buah salak.

2. Sebagai sumber informasi bagi peneliti yang selanjutnya, dalam memberikan masukan untuk penelitian lanjutan. 


\section{METODE PENELITIAN}

\section{Waktu dan Tempat Penelitian}

Penelitian ini dilaksanakan selama tiga bulan yaitu dimulai dari bulan Juni sampai bulan Agustus 2018. Tempat pelaksanaan di Desa Pangu Dua Kecamatan Ratahan Timur Kabupaten Minahasa Tenggara.

\section{Metode Pengumpulan Data}

Metode yang digunakan dalam penelitian ini adalah metode survei dengan cara mengambil data primer dan sekunder. Data primer diperoleh dengan mengajukan daftar pertanyaan kepada petani, pedagang pengumpul, pedagang pengecer di Desa Pangu Dua. Sedangkan data sekunder diperoleh dari pemerintah Desa Pangu Dua dan instansi instansi terkait yang berhubungan dalam penelitian ini.

\section{Metode Pengambilan Sampel}

Metode pangambilan sampel dilakukan dengan cara Purposive Sampling (secara sengaja), populasi dalam penelitian ini adalah semua petani buah salak yang ada di Desa Pangu Dua. Jumlah responden yang diambil adalah sebanyak 10 petani, karena disana homogen sehingga dari 10 petani sudah mewakili seluruh petani buah salak yang ada. Selanjutnya dilakukan metode pengambilan sampel lembaga pemasaran (pedagang pengumpul 5, pedagang besar 2, pedagang pengecer 3) yang terkait dalam pemasaran buah salak dengan cara Snowball Sampling, dimana sampel diperoleh berdasarkan informasi dari responden pertama yaitu petani buah salak, kemudian ditelusuri hingga ke konsumen akhir.

\section{Konsep Pengukuran Variabel}

Variabel-variabel yang akan diukur dalam penelitian ini, yaitu :

1. Karakteristik Responden :
a. Umur
b. Tingkat Pendidikan
c. Jumlah Tanggungan
d. Lama Berusahatani

2. Karakteristik Usahatani Buah Salak yang meliputi :
a. Luas lahan (Ha)
b. Jumlah produksi buah salak dalam satu kali panen $(\mathrm{Kg} / \mathrm{ha})$

3. Harga ditingkat petani yaitu penerimaan harga petani buah salak dari lembaga pemasaran $(\mathrm{Rp} / \mathrm{kg})$.

4. Harga di tingkat pedagang pengumpul adalah harga yang diterima dari pedagang pengumpul dari hasil penjualan kepada konsumen ( $\mathrm{Rp} / \mathrm{kg})$.

5. Harga ditingkat konsumen yaitu harga yang diterima konsumen dari penjualan di tingkat pengecer $(\mathrm{Rp} / \mathrm{kg})$.

6. Lembaga pemasaran dalam memasarkan buah salak
a. Biaya pengepakan/pengemasan ( $\mathrm{Rp})$
b. Biaya pengangkutan/transportasi (Rp)
c. Biaya tenaga kerja $(\mathrm{Rp})$
d. Biaya Retribusi (Rp)

\section{Metode Analisis Data}

Metode analisis data yang digunakan dalam penelitian di Desa Pangu Dua Kecamatan Ratahan Timur adalah :

a. Saluran pemasaran buah salak di Desa Pangu Dua Kecamatan Ratahan Timur dapat diketahui dengan mengikuti aliran pemasaran buah salak dari petani produsen sampai ke konsumen akhir.

b. Untuk mengetahui margin pemasaran dan biaya pemasaran di tingkat lembaga pemasaran pada saluran pemasaran digunakan analisis kuantitatif.

1. Margin pemasaran

$$
\text { Menurut Pearce dan Robinson (2011) }
$$

\section{Dimana :}

$$
\mathbf{M P}=\mathbf{P}_{\mathbf{r}}-\mathbf{P}_{\mathbf{f}}
$$

MP $=$ Margin Pemasaan

$\mathrm{P}_{\mathrm{r}}=$ Harga ditingkat Konsumen $(\mathrm{Rp} / \mathrm{kg})$

$P_{\mathrm{f}}=$ Harga ditingkat Produsen $/$ Petani $(\mathrm{Rp} / \mathrm{kg})$

2. Biaya Pemasaran

Menurut Rahim dan Hastuti (2007)

\begin{aligned} \multicolumn{1}{|c|}{$\mathbf{B p}=$} & $\mathbf{B p} \mathbf{1}+\mathbf{B p} \mathbf{2}+\mathbf{B p 3}+\ldots .+\mathbf{B p n} \\$ Dimana : & \\ $\mathrm{Bp} & =$ Biaya Pemasaran \\ $\mathrm{I} & =1,2,3 \ldots \\ . \mathrm{n} & =$ Jumlah Lembaga Pemasaran \\ $\mathrm{Bp} 1,2,3 . \mathrm{n}= &$ Biaya Pemasaran tiap Lembaga \\ & Pemasaran $(\mathrm{Rp} / \mathrm{Kg})\end{aligned}$

3. Keuntungan Pemasaran

\begin{tabular}{|l|}
\hline \multicolumn{1}{|c|}{$\mathbf{P}=\mathbf{M}-\mathbf{C}$} \\
Dimana : \\
$\mathrm{P}=$ Keuntungan Margin $(\mathrm{Rp} / \mathrm{kg})$ \\
$\mathrm{M}=$ Harga ditingkat Pedagang $(\mathrm{Rp} / \mathrm{Kg})$ \\
$\mathrm{C}=$ Biaya Pemasaran $(\mathrm{Rp} / \mathrm{Kg})$ \\
\hline
\end{tabular}


4. Farmer share

Sarma (1995) dalam Kaparang (2015).

\begin{tabular}{|l|}
\hline \multicolumn{2}{|c|}{ Fs $=\operatorname{Pf} / \operatorname{Pr} \times 100 \%$} \\
Dimana : \\
Fs = Bagian yang diterima petani \\
Pf = Harga ditinglat Petani $(\mathrm{Rp} / \mathrm{kg})$ \\
$\operatorname{Pr} \quad=$ Harga ditingkat Konsumen \\
\hline
\end{tabular}

\section{HASIL DAN PEMBAHASAN}

\section{Deskripsi Lokasi Penelitian Letak Geografis dan Luas Wilayah}

Desa Pangu Dua merupakan salah satu desa yang berada di Kecamatan Ratahan Timur. Kecamatan Ratahan Timur berada di Kabupaten Minahasa Tenggara Propinsi Sulawesi Utara, yang terdiri dari 10 desa dengan luas wilayah 6.399 Ha. Secara geografis desa Pangu Dua memiliki luas wilayah $234 \mathrm{Ha}$ dengan ketinggian $\pm 500 \mathrm{~m}$ diatas permukaan laut. Batas - batas wilayah Desa Pangu Dua yaitu:

- Sebelah Utara berbatasan dengan Desa Pangu

- Sebelah Selatan berbatasan dengan Kelurahan Nataan

- Sebelah Barat berbatasan dengan Desa Pangu

- Sebelah Timur berbatasan dengan Desa Pangu

\section{Jumlah Penduduk}

Penduduk di Desa Pangu Dua berjumlah 687 jiwa, yang mencakup penduduk yang bertempat tinggal tetap dan tidak tetap. Penduduk Desa Pangu Dua terdiri atas 202 KK dengan jumlah penduduk laki - laki 359 jiwa dan jumlah penduduk perempuan 328 jiwa.

\section{Mata Pencaharian}

Tingkat perekonomian di Desa Pangu Dua Kecamatan Ratahan Timur umumnya ditentukan oleh sektor pertanian. Sebagai mata pencaharian adalah bertani yang berkisar 90 persen dan sisa 10 persennya adalah jenis pekerjaan sebagai pegawai negeri sipil, swasta dan pedagang. Tanaman hortikultura yang paling banyak ditanam oleh petani di desa Pangu Dua Kecamatan Ratahan Timur yaitu buah salak, karena hampir semua penduduk membudidayakan buah salak.

\section{Kararakteristik Responden Petani Umur Petani}

Seseorang yang bekerja pada sektor pertanian pasti mengandalkan kemampuan fisik, sehingga fisik yang kuat dan sehat sangat diperlukan. Pada umumnya fisik seseorang yang masih muda dan sehat pasti berproduktivitas lebih besar dibandingkan dengan yang sudah tua. Makin tinggi umur seseorang maka akan semakin berkurang kemampuan seseorang untuk bekerja.

Kisaran umur responden petani buah salak di Desa Pangu Dua adalah 20-60 tahun. Sebagian besar responden petani berada pada kelompok umur 31-40 tahun. Jumlah petani pada kelompok umur ini yaitu sebanyak 7 orang petani atau 70,00 persen. Berdasarkan hasil penelitian dapat dikatakan bahwa petani yang berada di Desa Pangu Dua berada pada umur produktif.

\section{Tingkat Pendidikan Petani}

Pendidikan merupakan faktor yang sangat penting untuk meningkatkan sumber daya manusia, karena pendidikan dapat meningkatkan intelektual seseorang sehingga akan lebih mudah menerima dan memilah informasi - informasi untuk mengimplementasikan ke dalam usahataniya.

Tingkat pendidikan responden petanitermasuk dalam kategori cukup tinggi. Hal ini terlihat pada tingkat pendidikan SMA memiliki nilai presentase terbesar yaitu 50,00 persen dari total petani dengan jumlah responden petani 5 orang.

\section{Jumlah Tanggungan Petani}

Tingkat kesejahteraan keluarga dipengaruhi oleh berbagai faktor salah satunya yaitu jumlah tanggungan keluarga. Jumlah tanggungan berpengaruh pada pengeluaran keluarga, semakin banyak jumlah tanggungan semakin besar pengeluaran sehingga menyebabkan pendapatan petani lebih sedikit yang pada akhirnya menurunkan kesejahteraan keluarga petani. Akan tetapi, banyaknya jumlah tanggungan dalam kelurga juga membantu dalam hal penyediaan tenaga kerja, karena akan mengurangi permintaan tenaga kerja dari luar keluarga, dengan demikian mengurangi biaya tenaga kerja. 
Sebagian besar responden petani buah salak mempunyai jumlah tanggungan keluarga 2 orang. Jumlah responden petani yang memiliki tanggungan 2 yaitu 5 orang atau 50,00 persen dari total responden. Dari uraian tersebut dapat disimpulkan bahwa kesadaran petani akan keluarga berencana yang diterapkan pemerintah cukup tinggi.

\section{Pengalaman Bertani}

Keberhasilan usahatani tidak terlepas dari pengalaman petani dalam berusaha. Pengalaman usahatani juga berpengaruh terhadap pengetahuan dan keterampilan petani dalam mengalokasikan faktor produksi dalam penerapan teknologi baru maupun pemasarannya. Pengalaman petani dalam berusahatani buah salak di Desa Pangu Dua berkisar antara 5-18 tahun. Sebagian besar resoponden petani menjalankan usahatani buah salak berada pada 5-10 tahun sebanyak 7 orang atau 70,00 persen. Penduduk di Desa Pangu Dua Kecamatan Ratahan Timur pada umumnya telah lama menjalankan usahatani buah salak ini bahkan sudah sebagai mata pencaharian.

\section{Karakteristik Responden Lembaga Pemasaran Buah Salak Tingkat Umur}

Faktor umur dan kondisi fisik pedagang berpengaruh pada aktivitas pemasaran buah salak yang dijalankannya karena pada umumnya pedagang terlibat secara langsung baik selama proses pembelian maupun penjualan buah salak sehingga dibutuhkan pembelian buah salak dengan mendatangi petani secara langsung dan mengumpul, kemudian dijual ke pedagang luar atau pedagang pengecer.

Kisaran umur padagang perantara pemasaran buah salak di Desa Pangu Dua adalah 30-70. Sebagian besar responden pedagang perantara berada pada kelompok umur 30-40 tahun. Jumlah responden pedagang pengumpul sebanyak 2 responden atau 40,00 persen, pedagang pengecer sebanyak 2 responden atau 66,00 persen. Seelanjutnya dtingkat pedagang pengumpul pada umur 61-70 tahun sebanyak 2 responden atau 40,00 persen. Usia pedagang besar pada umur 51-60 tahun menunjukkan presentase yaitu sebanyak 2 responden atau 100 persen. Umur 41-50 tahun sebanyak 1 responden pedagang pengumpul 20,00 persen, dan 1 responden pedagang pengecer 34,00 persen. Dapat dilihat bahwa pedagang buah salak berada pada umur produktif sehingga diharapkan dengan umur yang masih peoduktif dapat memberikan kontribusi pemikiran dan fisik yang baik dalam menjalankan usahanya.

\section{Tingkat Pendidikan}

Faktor pendidikan mempengaruhi pengambilan keputusan yang dilakukan oleh pedagang dalam memasarkan buah salak. Pendidikan yang ditempuh dapat mempermudah pedagang dalam menjalankan usahanya terutama dalam perhitungan pendapatan serta penyerapan teknologi yang baru yang dapat menunjang usaha. Sehingga pedagang dapat mengikuti informasi pasar untuk harga buah salak dengan baik.

Pendidikan pedagang perantara desa Pangu Dua termasuk dalam kategori yang bervariasi. Hal ini terlihat pada tingkat pendidikan SMA 2 responden pedagang pengumpul 40,00 persen, 2 responden pedagang besar 100 persen dan 1 responden pedagang pengecer 34,00 persen. Sedangkan pada tingkat pendidikan SMP 2 responden pedagang pengumpul 40,00 persen dan 2 responden pedagang pengecer 66,00 persen. Dengan pendidikan pedagang demikian diharapkan dapat mempengaruhi daya serap sehingga dapat mengikuti informasi pasar mengenai harga buah salak dengan baik.

\section{Pengalaman Berdagang}

Pengalaman yang dimiliki pedagang dapat terlihat dari berapa lama mereka menjalankan usahanya dalam hal ini memasarkan buah salak. Pengalaman usaha membantu pedagang dalam mengamati dan memprediksi keadaan pasar sehingga pedagang dapat menentukan strategi pemasaran yang akan dijalankan.

Pengalaman dan lamanya dalam menekuni profesi sebagai pedagang baik pedagang pengumpul, pedagang pengecer, yang ada di Desa Pangu Dua yaitu pedagang 
pengumpul 5 tahun untuk 2 responden, 8 tahun untuk 2 responden dan 10 tahun 1 responden. Pengalaman berusaha dari pedagang pengecer yaitu 1 responden 10 tahun dan 2 responden 5 tahun.

\section{Usahatani Buah Salak}

\section{Luas Lahan}

Lahan merupakan faktor produksi yang memegang peranan penting bagi usahatani, karena lahan sangat dibutuhkan sebagai wadah untuk menanam komoditi atau tanaman yang ingin diusahakan oleh petani.

Jumlah petani yang mengelolah lahan untuk usahatani buah salak pada luas lahan 0,03 ha yaitu sebanyak 2 orang petani atau sekitar $20,00 \%$ dari total responden, sedangkan jumlah responden petani pada luas` lahan 0,05 ha yaitu sebanyak 6 orang petani atau $60,00 \%$ dari total responden petani dan luas lahan 1 ha yaitu sebanyak 2 orang petani atau $20,00 \%$ dari total responden.

\section{Produksi}

1. Jumlah Produksi

Jumlah produksi merupakan faktor penentu besarnya pendapatan yang akan diterima petani. Semakin besar volume produksi yang dihasilkan maka semakin tinggi pula penerimaan yang akan diterima.

Banyaknya produksi buah salak yang dihasilkan setiap petani bervariasi. Rata-rata jumlah produksi buah salak yang dihasilkan oleh petani Desa Pangu Dua adalah $75 \mathrm{~kg}$. Presentase tertinggi yaitu sebesar $50,00 \%$ dari total responden menghasilkan jumlah produksi $80 \mathrm{~kg}$ pada 5 responden petani.

\section{Harga Jual}

Harga merupakan cara untuk mengukur suatu barang atau jasa yang dinilai dengan uang guna memperoleh barang atau jasa tersebut. Harga jual adalah salah satu variabel penting terutama dalam menentukan besarnya penerimaan suatu usaha tani. Harga ditingkat petani yang digunakan dalam penelitian ini adalah harga yang berlaku pada bulan Mei sampai Agustus 2018, yaitu sebesar \pm Rp 5000,per kilogram. Harga ditingkat pengumpul yang digunakan dalam penelitian ini adalah harga yang berlaku pada bulan Mei sampai Agustus
2018, yaitu sebesar \pm Rp 7000.-per kilogram. Harga ditingkat pengecer yang digunakan dalam penelitian ini adalah harga yang berlaku pada bulan Mei sampai Agustus 2018, yaitu sebesar $\pm \mathrm{Rp}$ 15000.-per kilogram. Harga ditingkat konsumen yang digunakan dalam penelitian ini adalah harga yang berlaku pada bulan Mei sampai Agustus 2018, yaitu sebesar \pm 15000 ,- per kilogram.

\section{Lembaga Pemasaran Buah Salak di Desa Pangu Dua}

Kegiatan pemasaran buah salak dari produsen ke konsumen memerlukan pedagang perantara atau biasa disebut lembaga pemasaran. Berdasarkan penelitian didapati bahwa petani buah salak di Desa Pangu menggunakan jasa lembaga pemasaran untuk menyalurkan hasil produksi buah salak hingga sampai ke tangan konsumen. Masing - masing lembaga pemasaran mempunyai peranan penting dalam memasarkan buah salak.

1. Pedagang Pengumpul

Pedagang pengumpul merupakan pedagang yang melakukan aktiviitas membeli buah salak untuk dijual kembali. Pedagang pengumpul di Desa Pangu Dua membeli langsung buah salak dari petani dengan cara mendatangi petani, sehingga petani tidak perlu mengeluarkan biaya transportasi. Dalam satu kali pembelian pedagang pengumpul dapat membeli sebanyak rata-rata $592 \mathrm{~kg}$ buah salak. Pedagang pengumpul Desa Pangu akan membawa buah salak ke Kota Bitung, Amurang, Ternate. Selain itu juga pedagang pengumpul melakukan mitra dengan pedagang pengecer yang ada di pasar Swalayan di Manado (Golden).

\section{Pedagang Pengecer}

Pedagang pengecer merupakan pedagang perantara terakhir yang ditemukan pada saluran pemasaran. Hasil penelitian menunjukkan bahwa ada 3 pedagang pengecer di Desa Pangu Dua, dimana ketiga pedagang pengecer ini menjual buah salak langsung kepada konsumen akhir melalui kios-kios.

3. Pedagang Antar Pulau

Pedagang besar antar pulau membeli buah salak dari pedagang pengumpul kemudian memasarkan kembali. Penjualan buah salak 
antar pulau biasanya dilakukan karena telah terjadi kesepakatan terlebih dahulu atau telah berlangganan. Selanjutnya pedagang pen- gumpul Desa Pangu Dua membawa komoditi ke pedagang besar Ternate di Pelabuhan Laut Manado.

4. Konsumen

Konsumen merupakan orang yang membeli buah salak dari pedagang pengecer maupun lembaga pemasaran yang terlibat untuk dikonsumsi.

\section{Saluran Pemasaran Buah Salak di}

Desa Pangu Dua Kecamatan Ratahan Timur

Saluran pemasaran merupakan serangkaian lembaga yang melakukan semua fungsi yang digunakan untuk menyalurkan barang dari produsen ke konsumen. Pola saluran pemasaran buah salak dapat diketahui dengan cara mengikuti arus pemasaran buah salak mulai dari petani produsen sampai kepada konsumen. Berdasarkan hasil penelitian yang telah dilaksanakan, menunjukkan ada 4 saluran pemasaran buah salak di Desa Pangu Dua Kecamatan Ratahan Timur yaitu :

\section{Saluran Pemasaran I}

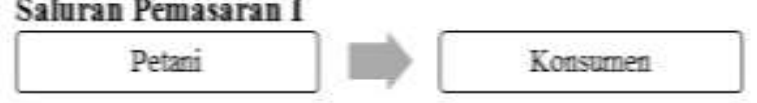

Pola pemasarannya petani menjual langsung hasil panen buah salak dari kebun ke kios-kios milik petani di Desa Pangu Dua. Saluran pemasaran ini disebut saluran nol tingkat.

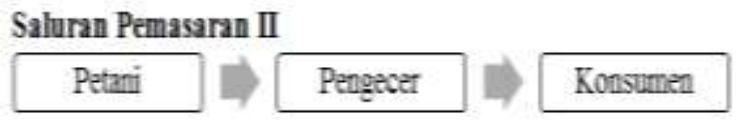

Pola pemasarannya pedagang pengecer desa membeli langsung buah salak dari petani dalam partai kecil kemudian memasarkan kembali ke konsumen melalui kios-kios milik sendiri di Desa Pangu Dua. Saluran pemasaran ini disebut saluran satu tingkat.

Saluran Pemasaran III

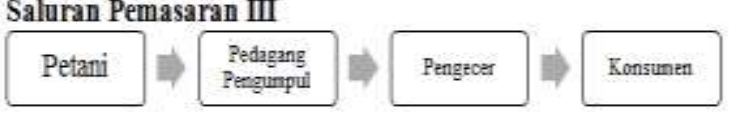

Pola pemasarannya, pedagang pengumpul desa melakukan mitra dengan pedagang pengecer yang ada di pasar Swalayan di Manado (Jumbo dan Golden). Saluran pemasaran ini disebut saluran dua tingkat.

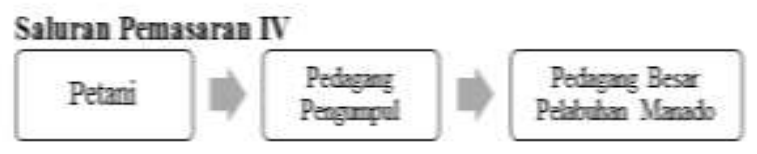

Pola pemasarannya pedagang pengumpul menjual ke pedagang besar Ternate dengan melakukan pertemuan di Pelabuhan Laut Manado.

\section{Margin Pemasaran dan Farmer's Share}

Berdasarkan hasil penelitian diketahui ada empat jenis saluran pemasaran buah salak yang terjadi di Desa Pangu Dua Kecamatan Ratahan Timur. Dengan adanya jumlah lembaga pemasaran yang terlibat pada setiap saluran pemasaran menyebabkan margin pemasaran yang berbeda.

\section{Margin Pemasaran dan Farmer's Share pada Saluran Pemasaran I}

Rata-rata biaya, keuntungan, margin pemasaran dan farmer'share pada saluran pemasaran I dapat dilihat pada Tabel 2 berikut ini :

\begin{tabular}{|c|c|c|}
\hline Krompoxen Bimy & Harra (Rp Kg) & Share (S) \\
\hline Petani & & \\
\hline $\begin{array}{l}\text { Harga jual } \\
\text { Biaya Pesmasana: }\end{array}$ & 15.000 & 100,00 \\
\hline 1. Pengangkitan & 133,4 & 0,89 \\
\hline 2. Sotir dan Peagemasan & 200 & 1,33 \\
\hline 3. Tenaga Kerja & 1,666 & 0,01 \\
\hline 4. Kios dan Peryimpanan & 200,44 & 1,34 \\
\hline Total Biaya & 535,50 & 3,57 \\
\hline Harga Beli Konsumen Aldir & 15000 & \\
\hline Fanwer's Shave (9) & & 100,00 \\
\hline
\end{tabular}

Tabel 2 menunjukkan bagian yang diterima petani adalah 100 persen. Rata-rata biaya pemasaran pada saluran pemasaran I yaitu Rp. 535,50 atau 3,57 persen dengan perincian biaya antara lain pengangkutan (digunakan alat transportasi yaitu sepeda motor), sortir dan pengemasan, tenaga kerja untuk satu orang dan kios serta penyimpanan. Saluran pemasaran ini petani menjual buah salak langsung ke konsumen akhir di Desa Pangu Dua melalui kios. Disini petani juga bersifat sebagai pedagang. Terdapat 2 responden petani yang menjual buah salak pada saluran pemasaran I dengan presentase $20 \%$.

\section{Margin Pemasaran dan Farmer's Share pada Saluran Pemasaran II}

Rata-rata biaya, keuntungan, margin pemasaran dan farmer's share pada saluran II dapat dilihat pada Tabel 3 berikut ini : 


\begin{tabular}{|c|c|c|}
\hline Koetpoens Blays & Harpa (lpike) & Share $(46)$ \\
\hline \multicolumn{3}{|l|}{ Prenan Baah Salak. } \\
\hline Hepa fual & 7800 & 46.6 \\
\hline Harge Beli Prdagane Prengecer & 7000 & 46.69 \\
\hline \multicolumn{3}{|l|}{ Biays Penaaurat: } \\
\hline - Pmpazikatan & 272.4 & 1.92 \\
\hline - Presenatan & 340 & 2.27 \\
\hline - Kies dan Perginapenam & 204,45 & 1.36 \\
\hline Total Biegn & 816,84 & 545 \\
\hline Keuthungat & 7.183 & 97,60 \\
\hline Merein & 8000 & 53) \\
\hline Harga fual Ke Koesumen & 15000 & 100.00 \\
\hline Fandis inere (s) & & 4657 \\
\hline
\end{tabular}

Tabel 3 menunjukkan biaya pemasaran yang dikeluarkan pedagang pengecer antara lain pengangkutan buah salak langsung dari petani yaitu Rp. 272,4 atau 1,82 persen pengemasan di dalamnya ada biaya kantong plastik, penyimpanan, kios dengan total biaya $\mathrm{Rp} \mathrm{816,85}$ atau 5,45 persen. Pada saluran pemasaran II hanya melalui lembaga pemasaran yaitu pedagang pengecer. Pedagang pengecer mendapatkan keuntungan sebesar Rp 7.183 atau 47,89 persen.

Hasil analisis menunjukkan margin pemasaran pada saluran II adalah $\mathrm{Rp} 8.000$ atau 53,33 persen, sedangkan bagian yang diterima petani (farmer's share) pada saluran pemasaran II yaitu 46,67 persen. Terdapat 3 responden petani yang menjual buah salak pada saluran pemasaran II dengan presentase $30 \%$.

\section{Margin Pemasaran dan Farmer's Share pada Saluran Pemasaran III}

Bentuk atau pola pemasaran III ini terjadi pada pemasaran buah salak di pasar swalayan (Golden) di Manado. Rata-rata biaya, keuntungan, margin pemasaran dan farmer's share pada saluran III dapat dilihat pada Tabel 4 berikut ini :

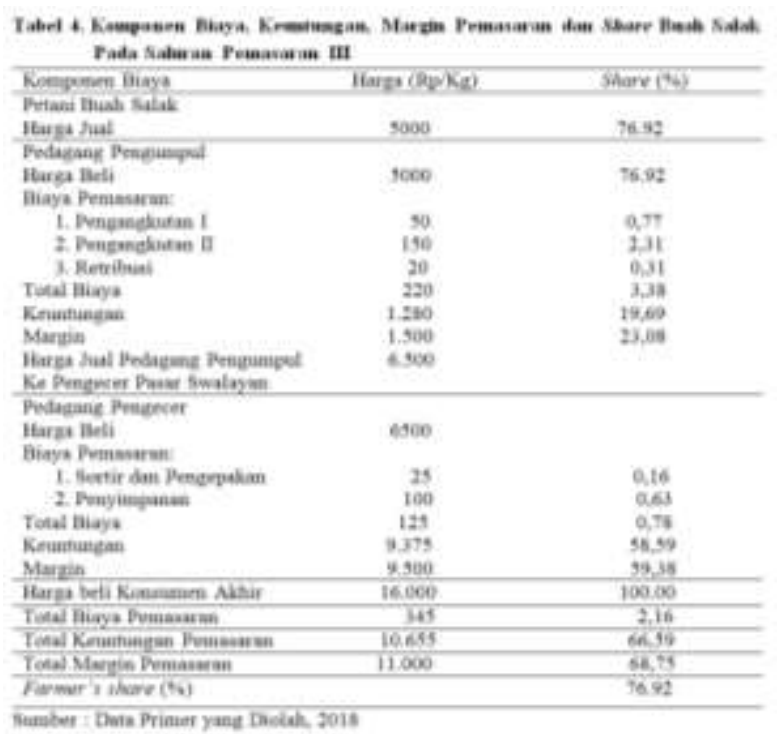

Tabel 4 menunjukkan bahwa pada lembaga pemasaran pertama yaitu ditingkat pedagang pengumpul, harga beli buah salak Rp 5.000 per kg dan dijual ke pedagang pengecer dengan harga $\mathrm{Rp} 6.500$ per $\mathrm{kg}$. Total biaya pemasaran pada saluran pemasaran III yaitu sebesar Rp 345 atau 2,16 persen. Total biaya pemasaran yang dikeluarkan oleh pedagang pengumpul lebih besar yaitu Rp 220 atau 3,38 persen, disebabkan oleh biaya transportasi buah salak dilakukan dengan menggunakan mobil pick up.

Pada lembaga pemasaran kedua yaitu ditingkat pedagang pengecer harga beli buah salak dari pedagang pengumpul yaitu sebesar Rp 6.500 per $\mathrm{kg}$ dan dijual ke konsumen akhir dengan harga Rp 16.000 per $\mathrm{kg}$. Total biaya pemasaran pada tingkat pedagang pengecer yaitu sebesar Rp 125 atau 0,78 persen.

Keuntungan yang diperoleh pedagang pengumpul sebesar Rp. 1.280 atau 19,69 persen dan pedagang pengecer mendapatkan keuntungan sebesar Rp. 9.375 atau 58,59 persen. Pedagang pengecer hanya mengeluarkan biaya sortir dan pengepakan, penyimpanan, sehingga keuntungan yang diperoleh jauh lebih besar dari pedagang pengumpul. Hasil analisis juga menunjukkan total margin pemasaran pada saluran pemasaran III yaitu sebesar Rp 11.000 atau 68,75 persen dengan perincian margin pemasaran dtingkat pedagang pengumpul Rp 1.500 atau 23,08 persen dan margin pemasaran ditingkat pedagang pengecer Rp 9.500 atau 59,38 persen. Bagian yang diterima oleh petani petani (farmer's share) pada saluran pemasaran III yaitu sebesar 76,92 persen. Terdapat 3 responden petani yang menjual buah salak pada saluran pemasaran III dengan presentase $30 \%$.

\section{Margin Pemasaran dan Farmer's Share pada Saluran Pemasaran IV \\ Rata-rata biaya, keuntungan, margin} pemasaran dan farmer's share pada saluran IV dapat dilihat pada Tabel 5 berikut ini :

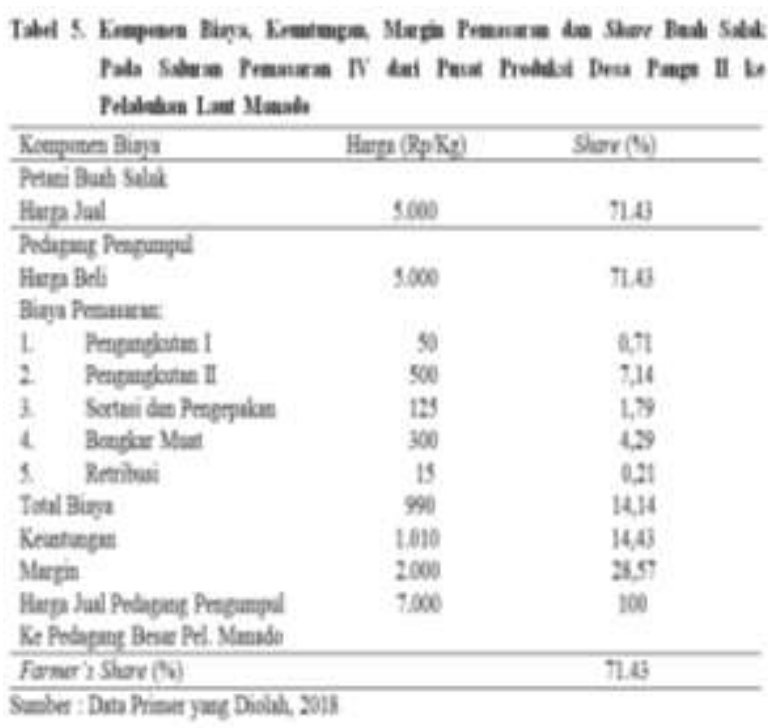


Tabel 5 menunjukkan bahwa pada tingkat pedagang pengumpul harga beli buah salak dari petani yaitu sebesar Rp 5.000 per kg dan harga jual ke pedagang besar antar pulau yaitu sebesar $\mathrm{Rp}$ 7.000 per $\mathrm{kg}$. Pedagang pengumpul mengeluarkan biaya $\mathrm{Rp} 990$ atau 14,14 persen, disebabkan oleh jarak yang cukup jauh sehingga pengangkutan dilakukan 2 kali dengan biaya transportasi yang besar dan menggunakan mobil pick up sampai pada pedagang besar antar pulau di Manado. Keuntungan pemasaran yang diperoleh pada saluran pemasaran IV yaitu sebesar Rp 1.010 atau 16,57 persen. Total margin pemasaran pada saluran IV yaitu sebesar Rp 2.000 atau 28,57 persen. Sedangkan bagian yang diterima oleh petani (farmer's share) pada saluran pemasaran IV yaitu sebesar 71,43 persen. Terdapat 2 responden petani yang menjual buah salak pada saluran pemasaran IV dengan presentase $20 \%$.

\section{Margin Pemasaran dan Farmer's Share Seluruh Saluran Pemasaran Buah Salak di Desa Pangu Dua}

Hasil penelitian yang terangkum pada Tabel 6 bahwa petani buah salak di Desa Pangu Dua Kecamatan Ratahan Timur dalam memasarkan hasil komoditinya mengandalakan pedagang pengumpul. Sehingga rata-rata harga jual tingkat petani pada setiap saluran pemasaran adalah Rp 5.400 per $\mathrm{kg}$. Harga jual buah salak ini mengalami perubahan dan perbedaan pada setiap saluran pemasaran setelah di tingkat pedagang pengumpul. Hal ini disebabkan pedagang pengumpul mendistribusikan buah salak ke lokasi-lokasi melibatkan lembaga-lembaga pemasaran (pedagang perantara) yaitu pedagang pengecer pasar swalayan dan pedagang besar di Pelabuhan Laut Manado. Keterlibatan pedagang perantara jelas akan berpengaruh pada harga jual buah salak karena masing-masing pedagang perantara pasti ingin memperoleh keuntungan pemasaran. Harga jual, total biaya, keuntungan, margin pemasaran dan farmer's share pada setiap saluran pemasaran di Desa Pangu Dua Kecamatan Ratahan Timur Kabupaten Minahasa Tenggara terangkum pada Tabel 6 berikut ini :

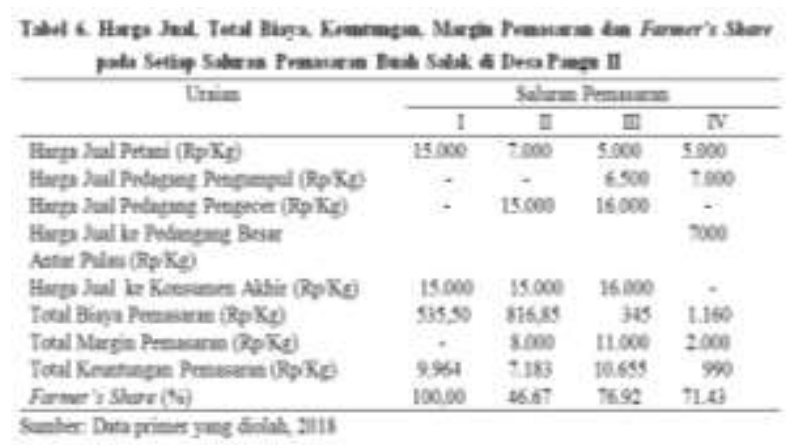

Tabel 6 menunjukkan margin pemasaran dan keuntungan pemasaran pada saluran pemasaran III menghasilkan nilai tertinggi yaitu masing-masing sebesar Rp 11.000 per $\mathrm{kg}$ dan $\mathrm{Rp} 10.655$ per $\mathrm{kg}$ dengan total biaya $\mathrm{Rp} 345$ per $\mathrm{kg}$.

Kondisi tersebut memungkinkan karena pada saluran pemasaran III melibatkan dua pedagang perantara. Selain itu jarak tempuh yang cukup jauh dan permintaan kuantitas komoditi buah salak dalam jumlah banyak mengakibatkan biaya yang dikeluarkan menjadi lebih tinggi sehingga margin pemasaran yang terbentuk pun menjadi tinggi.

Berdasarkan uraian tersebut, maka dapat disimpulkan bahwa farmer's share tertinggi berada pada saluran pemasaran I yaitu sebesar 100 persen, diikuti saluran pemasaran III sebesar 76,92 persen dan saluran IV sebesar 71,43 persen, kemudian saluran pemasaran II sebesar 46,67 persen.

\section{KESIMPULAN DAN SARAN}

\section{Kesimpulan}

Saluran pemasaran yang terbentuk pada pemasaran buah salak di Desa Pangu Dua Kecamatan Ratahan Timur Kabupaten Minahasa Tenggara diperoleh ada 4 bentuk saluran pemasaran.

Saluran Pemasaran buah salak di Desa Pangu Dua menghasilkan biaya, margin pemasaran dan keuntungan pemasaran. Saluran pemasaran buah salak di Desa Pangu Dua yang menghasilkan biaya, margin, dan keuntungan pemasaran tertinggi pada saluran pemasaran III yaitu total biaya sebesar Rp 345 per kilogram, margin pemasaran sebesar Rp 11.000 per kilogram, dan keuntungan sebesar Rp 10.655 per kilogram. Bagian yang diterima petani (farmer's share) tertinggi pada saluran pemasaran I yaitu sebesar 100 persen.

\section{Para petani lebih meningkatkan} pemasaran buah salak karena peluang pemasaran buah salak baik di dalam maupun diluar daerah memiliki prospek yang sangat baik untuk terus dikembangkan.

Lembaga- lembaga pemasaran yang ada agar lebih meningkatkan kerjasama dalam kegiatan usahatani dan pemasaran buah salak sehingga baik petani maupun lembaga pemasaran yang ada dapat menerima harga yang layak.

Agrisosioekonomi: 


\section{DAFTAR PUSTAKA}

Badan Pusat Statistik dan Direktorat Jendral Hortikultura, 2007.

Fatimah N. S, 2011. Analisis Pemasaran Kentang (Solanum Tuberosum L.) Di Kabupaten Wonosobo. Skripsi Jurusan Sosial Ekonomi Fakultas Pertanian Universitas Sebelas Maret Surakarta.

Kaparang R, 2015. Margin Pemasaran Bawang Merah di Desa Tonsewer Kecamatan Tompaso. Skripsi Jurusan Sosial Ekonomi Fakultas Pertanian Unsrat, Manado.

Manurung, V. H., Djarkasi G. S. S., dan Lalujan, L. E., 2008. Analisis Sifat Fisik Dan Kimia Buah Salak Pangu (Salacca Zalacca) Dengan Pelilinan Selama Penyimpanan. Fakultas Pertanian Unsrat, Manado.
Pearce dan Robinson, 2011. Manajemen Strategis; Formulasi, Implementasi dan Pengendalian. Jakarta: Penerbit Salemba Empat.

Rahim A dan Hastuti, 2007. Ekonomi Pertanian. Jakarta : Penerbit Penebar Swadaya.

Tambulus C., 2015. Kontribusi Usaha Tani Salak Terhadap Pendapatan Keluarga Petani di Wilayah Pangu Kecamatan Ratahan Timur. Jurnal Sosial Ekonomi Fakultas Pertanian Unsrat.

Woran R. F., Nangoy R., dan Lengkong, J. E., 2018. Kajian Sifat Fisik dan Kimia Tanah Pada Areal Pertanaman Salak (Salacca zalacca) di Desa Pangu Kabupaten Minahasa Tenggara. Jurnal Agroekoteknologi Fakultas Pertanian Unsrat, Manado. 